\title{
C.
}

\section{Two Xanthic Spotted Brown Tropes, Tropidophis pardalis (Squamata, Tropidophiidae), in Havana, Western Cuba}

\author{
Javier Torres ${ }^{1}$, Ruben Marrero², Orlando J. Torres ${ }^{1}$, and Víctor M. Ramírez
}

${ }^{1}$ Departamento de Biología Animal y Humana, Facultad de Biología, Universidad de la Habana, CP 10400, La Habana, Cuba (javiertorres@fbio.uh.cu) ${ }^{2}$ División de Zoología de Vertebrados, Instituto de Ecología y Sistemática, Calabazar, Boyeros, La Habana, CP 11900, Cuba

${ }^{3}$ Facultad de Biología (student), Universidad de la Habana, CP 10400, La Habana, Cuba

$\mathrm{T}$

The Spotted Brown Trope (Tropidophis pardalis) is one of 16 Cuban species of Tropidophis; all are endemic (Henderson and Powell 2009). It has a wide, albeit discontinuous, distribution and is most frequently found in western
Cuba (Schwartz and Henderson 1991, Rodríguez et al. 2013). It is a small, relatively common, nocturnally active, grounddwelling snake found in a wide variety of habitats (Schwartz and Henderson 1991). Its secretive behavior is enhanced by
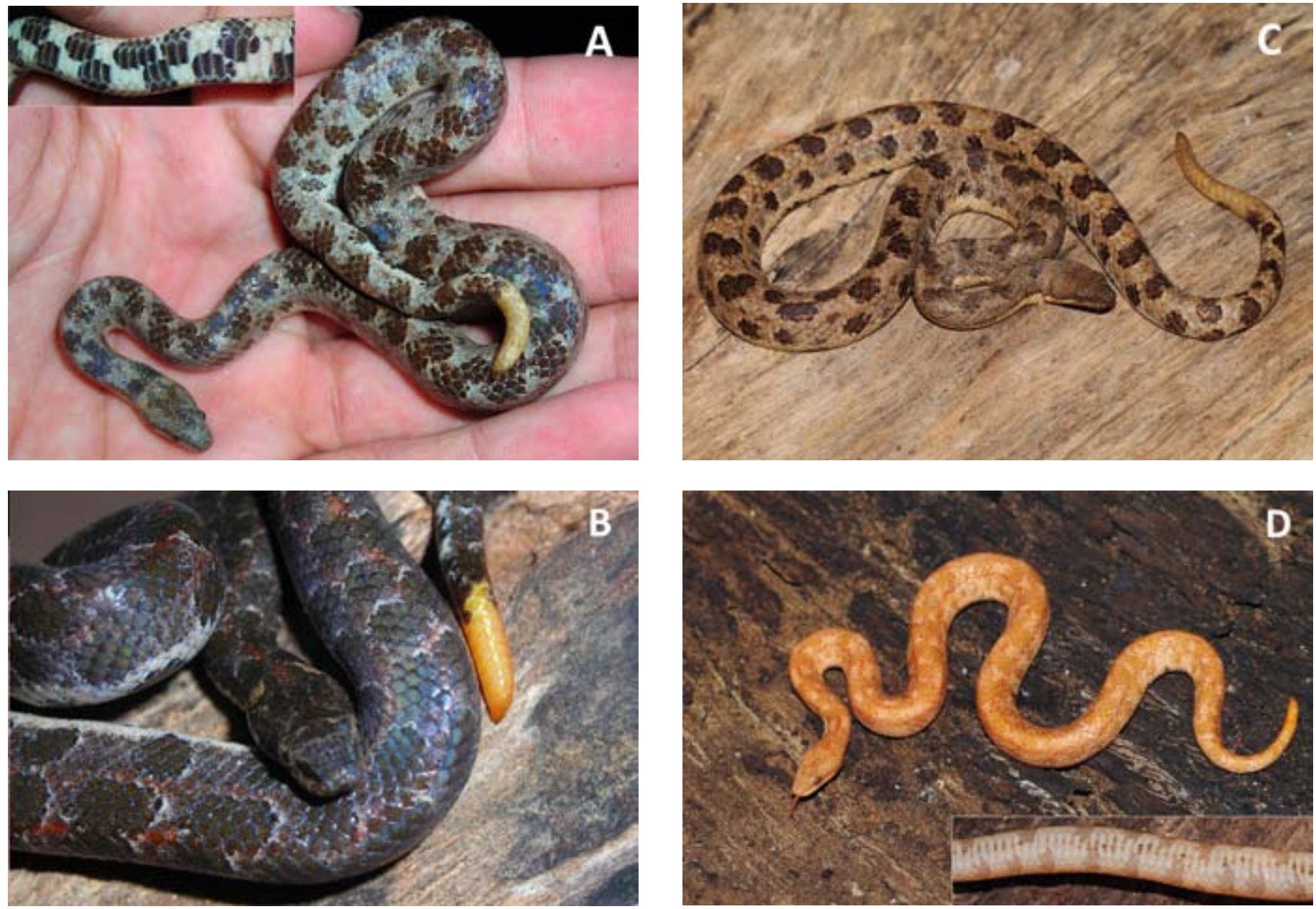

Figure 1. Tropidophis pardalis: (A) Typical morph (adult in light phase); insert showing ventral pattern. (B) Typical morph (immature in dark phase). (C) Cinnamon morph (adult in transition phase). (D) Xanthic morph (adult); insert showing ventral pattern. Photographs by Javier Torres (A-B) and Ruben Marrero (C-D). 
Table 1. Comparison of xanthic and non-xanthic Tropidophis pardalis morphs. All characters refer to color traits except when specified. Most of these traits are evident in Fig. 1. The order in which elements appear in multi-state cases is not indicative of frequency. $\mathrm{N}=$ number of specimens examined.

\begin{tabular}{lcc} 
Character & $\begin{array}{c}\text { Xanthic Morphs } \\
\mathbf{N}=2\end{array}$ & $\begin{array}{c}\text { Non-xanthic Morphs } \\
\mathbf{N}=\mathbf{2 8}\end{array}$ \\
\hline Tongue (except tip) & red & brown to black \\
\hline Tongue tip & rosy & white \\
\hline Post-nasal band & reddish & brown \\
\hline Iris & gray & gray, brown \\
\hline Pupil & red & black \\
\hline Presence of ocular bar & no & yes \\
\hline Presence of occipital spots or neck band & no & gray to brown, reddish \\
\hline Dorsal ground color & whitish to yellowish & orange, reddish \\
\hline Longitudinal stripes & reddish & brown to black \\
\hline Dorsolateral spots & yellow & dark brown, black \\
\hline Ventral spots & pale brown & light brown, yellow, orange \\
\hline Tail & orange & high \\
\hline Contrast between body and tail & slight &
\end{tabular}

cryptic dorsal coloration, which is characterized by irregular black spots sometimes combining to form crossbands on a cinnamon to dark brown background. The venter has two rows of spots on a white to beige background. The tail tip can be yellow, orange, or light brown (Fig. 1A-C).

Herein we report the discovery of two xanthic individuals. On 5 October 2012 at 1030 h, we found an adult female T. pardalis (MFP $12503^{1}$ ) under a flat stone in a residential backyard $\left(23.07755^{\circ} \mathrm{N},-82.44001^{\circ} \mathrm{W}\right.$; datum: NAD27) at Marianao, La Habana, Cuba. Nine months later (7 June 2013 at 1530 h), we found another xanthic adult (Fig. 1D) at the same locality, also under a rock, but approximately $10 \mathrm{~m}$ from the first snake. We compared xanthic and non-xanthic morphs (Table 1) using photographs of 30 live snakes from La Habana (23 + 2 xanthic), Artemisa (2), Pinar del Río (1), Cienfuegos (1), and Sancti Spiritus (1).

Like other tropidophiids that change cyclically from light to dark phases (Rehak 1987, Hedges et al. 1989), T. pardalis exhibits a physiological circadian pattern (Fig. 1). However, neither xanthic individual exhibited different color phases, probably attributable to the near absence of melanin (Fig. 1D), the pigment responsible for the dark phase (Hedges et al. 1989).

\footnotetext{
${ }^{1}$ MFP is the acronym for the Museum of Natural History "Felipe Poey" at the Faculty of Biology, University of Havana, Cuba.
}

Conspicuous coloration patterns generally are unfavorable for concealment, although nocturnal activity may have contributed to the survival of these individuals. The close proximity of the two xanthic snakes and their very similar sizes suggest that they were siblings, especially since xanthism appears to be very rare in $T$. pardalis.

\section{Acknowledgements}

We thank colleagues and students who help in the acquisition of photographs: Javier Usatorres, Lázaro Cuellar, Raimundo LópezSilvero, Roberto Alonso and Tomás M. Rodríguez (in alphabetical order). We also thank Elier Fonseca for reviewing the manuscript and an anonymous reviewer for helpful comments.

\section{Literature Cited}

Hedges, S.B. 2002. Morphological variation and the definition of species in the snake genus Tropidophis (Serpentes, Tropidophiidae). Bulletin of the Natural History Museum of London (Zoology) 68:83-90.

Hedges, S.B., C.A. Hass, and T.K. Maugel. 1989. Physiological color change in snakes. Journal of Herpetology 23:450-455.

Henderson, R.W. and R. Powell. 2009. Natural History of West Indian Reptiles and Amphibians. University Press of Florida, Gainesville.

Rehak, I. 1987. Color change in the snake Tropidophis feicki (Reptilia: Squamata: Tropidophiidae). Vestník Ceskoslovenské Spolecnosti Zoologické 51:300-303.

Rodríguez, L., C.A. Mancina, and V. Rivalta. 2013. Reptiles of Cuba: Checklist and geographic distributions. Smithsonian Herpetological Information Service 144:1-96.

Schwartz, A. and R.W. Henderson. 1991. Amphibians and Reptiles of the West Indies: Descriptions, Distributions, and Natural History. University of Florida Press, Gainesville. 